\title{
Arsenic trioxide and sorafenib combination therapy for human hepatocellular carcinoma functions via up-regulation of TNF-related apoptosis-inducing ligand
}

\author{
LINGYAN WANG ${ }^{1-3^{*}}$, ZHIHUI MIN ${ }^{1-3^{*}}$, XIANGDONG WANG ${ }^{1-3}$, MUSHUANG HU ${ }^{1}$, \\ DONGLI SONG ${ }^{1-3}$, ZHENGGANG REN $^{6}$, YUNFENG CHENG ${ }^{1-5}$ and YANHONG WANG ${ }^{6}$ \\ ${ }^{1}$ Institute of Clinical Science; ${ }^{2}$ Biomedical Research Center, Zhongshan Hospital, Fudan University; \\ ${ }^{3}$ Shanghai Institute of Clinical Bioinformatics; ${ }^{4}$ Department of Hematology, Zhongshan Hospital, Fudan University, \\ Shanghai 200032; ${ }^{5}$ Department of Hematology, Zhongshan Hospital Qingpu Branch, Shanghai 201700; \\ ${ }^{6}$ Liver Cancer Institute, Zhongshan Hospital, Fudan University, Shanghai 200032, P.R. China
}

Received October 24, 2017; Accepted April 27, 2018

DOI: $10.3892 / \mathrm{ol} .2018 .8981$

\begin{abstract}
The survival benefits of sorafenib treatment for patients with hepatocellular carcinoma (HCC) are limited due to drug resistance and side effects. Therefore, combinations of sorafenib with other low toxicity drugs, including arsenic trioxide $\left(\mathrm{As}_{2} \mathrm{O}_{3}\right)$ require investigation. The present study aimed to evaluate the potency of apoptosis-induction by $\mathrm{As}_{2} \mathrm{O}_{3} /$ sorafenib treatment in $\mathrm{HCC}$ cell lines, $\mathrm{Huh} 7,97 \mathrm{H}$ and freshly-isolated HCC cells, and also to elucidate the underlying mechanism. A total of 10 patients with HCC were enrolled in the present study. Freshly-isolated HCC cells were purified from HCC tissues collected at surgery. HCC-cell apoptosis was measured by flow cytometry using proprium iodide/Annexin-V staining. The impacts of $\mathrm{As}_{2} \mathrm{O}_{3}$ and/or sorafenib on Huh7, 97H and fresh-isolated HCC-cell proliferation were evaluated by Cell Counting Kit- 8 assay.
\end{abstract}

Correspondence to: Dr Yanhong Wang, Liver Cancer Institute, Zhongshan Hospital, Fudan University, 180 Fenglin Road, Shanghai 200032, P.R. China

E-mail: 18121317526@163.com

Dr Yunfeng Cheng, Department of Hematology, Zhongshan Hospital, Fudan University, 180 Fenglin Road, Shanghai 200032, P.R. China

E-mail: yfcheng@fudan.edu.cn

${ }^{*}$ Contributed equally

Abbreviations: HCC, human hepatocellular carcinoma; HBV, hepatitis $\mathrm{B}$ virus; $\mathrm{HCV}$, hepatitis $\mathrm{C}$ virus; $\mathrm{RF}(\mathrm{T}) \mathrm{A}$, radiofrequency (thermal) ablation; VEGF, vascular endothelial growth factor; $\mathrm{As}_{2} \mathrm{O}_{3}$, arsenic trioxide; APL, acute promyelocytic leukemia; TRAIL, TNF-related apoptosis-inducing ligand; MAPK, mitogen-activated protein kinase; PI3K, phosphatidylinostol-3-kinase; PCD, programmed cell death

Key words: human hepatocellular carcinoma, sorafenib, $\mathrm{As}_{2} \mathrm{O}_{3}$, TNF-related apoptosis-inducing ligand, apoptosis
The expression of TNF-related apoptosis-inducing ligand (TRAIL) was determined by reverse transcription-quantitative polymerase chain reaction and western blotting. The downregulation of TRAIL protein expression was achieved using small interfering RNA. The combination of $\mathrm{As}_{2} \mathrm{O}_{3}$ and sorafenib had anti-proliferative and pro-apoptotic effects in the liver cancer cell line, Huh7, via increased expression of TRAIL, but not in $97 \mathrm{H}$ cells. TRAIL-knockdown increased the drug-resistance of Huh7 cells. Freshly-isolated HCC cells were more sensitive to the $\mathrm{As}_{2} \mathrm{O}_{3}$ and sorafenib combination than the single drug treatments. Overall, the combination of $\mathrm{As}_{2} \mathrm{O}_{3}$ and sorafenib demonstrated potent anti-tumor activity in Huh7 and freshly-isolated HCC cells via a TRAIL-dependent pathway. This may be a potential therapeutic approach for advanced HCC treatment.

\section{Introduction}

As the second leading cause of cancer-associated mortality in men, and the sixth in women worldwide (1), human hepatocellular carcinoma (HCC) remains a severe global health threat. Chronic infections of hepatitis B virus (HBV) and hepatitis C virus (HCV) are major risk factors associated with HCC (2). With an increased rate of $\mathrm{HBV} / \mathrm{HCV}$ infection and other risk factors, including obesity, cigarette smoking, diabetes mellitus and heavy alcohol consumption, the incidence of HCC has also increased (3). In order to prevent HCC progression, tumor resection, liver transplantation and radiofrequency (thermal) ablation $[\mathrm{RF}(\mathrm{T}) \mathrm{A}]$ are commonly used for HCC treatment (4-6). Although these treatments have improved the survival rates of patients with HCC, they are only appropriate for a minority of patients, and their efficacies are limited by high recurrence rates (7). Hence, new systemic therapies for HCC are urgently required.

Sorafenib, an oral multi-kinase inhibitor, can block certain signaling pathways, including those of Raf kinase and vascular endothelial growth factor (VEGF) (8). Multiple phase III clinical studies have indicated its effect of improving the survival of patients with $\mathrm{HCC}$ and delaying radiological 
progression (9). Therefore, it has been proposed as the standard treatment for patients with advanced HCC. Considering its strong effect on the suppression of angiogenesis and the induction of apoptosis (10), it has also been approved for the treatment of other types of advanced cancer, including renal cell carcinoma (11), breast cancer (12) and leukemia (13). However, the survival benefits for patients with HCC treated with sorafenib treatment are modest due to individual variation and toxicity (14). The establishment of sorafenib-based therapeutic combination options is required to improve the overall survival rate of patients with HCC.

Arsenic trioxide $\left(\mathrm{As}_{2} \mathrm{O}_{3}\right)$, a traditional Chinese medicine, has been widely used to treat acute promyelocytic leukemia (APL) (15). It induces differentiation at low concentrations $(<0.5 \mu \mathrm{M})$ and increases apoptosis at higher concentrations (0.5-2.0 $\mu \mathrm{M})$ in APL cells (16). Previous studies have used $\mathrm{As}_{2} \mathrm{O}_{3}$ to treat various types of solid cancer, including small cell lung cancer (17) and colon cancer (18). Despite its ability to inhibit hepatocellular tumor growth and cell apoptosis in vitro (19), a phase II clinical trial reported that $\mathrm{As}_{2} \mathrm{O}_{3}$ had limited activity against advanced $\mathrm{HCC}$ (20). On the other hand, a different study demonstrated that $\mathrm{As}_{2} \mathrm{O}_{3}$ potentiated the anticancer activity of sorafenib in $\mathrm{HCC}$ by inhibiting Akt activation (21). $\mathrm{As}_{2} \mathrm{O}_{3}$ in combination with chemotherapy is now considered to have potential in cancer therapeutics (22). However, the effect of sorafenib/ $\mathrm{As}_{2} \mathrm{O}_{3}$ combination on primary $\mathrm{HCC}$ cells and the underlying mechanisms remain to be elucidated.

TNF-related apoptosis-inducing ligand (TRAIL), also known as Apo2L, is a member of the TNF superfamily with potential for anticancer therapy (23). TRAIL induces apoptosis through interacting with its receptors, death receptor (DR)4 and 5, causing tumor-cell death (24). The upregulation of TRAIL expression is directly involved in the inhibition of tumor initiation and metastasis $(25,26)$. However, regulation of the TRAIL ligand remains poorly understood compared with TRAIL receptor-binding.

To provide a novel solution to sorafenib-resistance in $\mathrm{HCC}$, the present study aimed to evaluate the efficacy of $\mathrm{As}_{2} \mathrm{O}_{3}$ /sorafenib combined treatment against primary $\mathrm{HCC}$ cells and its impact on TRAIL expression. We hypothesized that the synergistic interaction of $\mathrm{As}_{2} \mathrm{O}_{3}$ and sorafenib would induce apoptosis of HCC cells via a TRAIL-dependent pathway. Furthermore, this synergistic effect was analyzed in fresh-isolated HCC cells.

\section{Materials and methods}

Isolation of fresh HCC cells. A total of 10 patients with HCC, including 4 females and 6 males, aged between 48 and 79 years, with a median age of 62 years, who were either HBV- or HCV-positive underwent surgical resection at Zhongshan Hospital (Shanghai, China) between January 2013 and December 2014. HCC tissues were collected at surgery, washed in Hank's solution $(8.0 \mathrm{~g} \mathrm{NaCl}, 0.2 \mathrm{~g} \mathrm{KCl}, 0.2 \mathrm{~g}$ $\mathrm{Na}_{2} \mathrm{HPO}_{4} \cdot \mathrm{H}_{2} \mathrm{O} 1.56 \mathrm{~g}, \mathrm{KH}_{2} \mathrm{PO}_{4}$ in 11 distilled water) and sliced into $0.5-1.0-\mathrm{mm}^{3}$ sections. Sections were incubated with $5-10 \mathrm{ml}$ collagenase containing penicillin $(100 \mathrm{U} / \mathrm{ml}) /$ streptomycin $(100 \mathrm{mg} / \mathrm{ml})$ at $37^{\circ} \mathrm{C}$ for $30 \mathrm{~min}$, and centrifuged at $4^{\circ} \mathrm{C}$, $300 \mathrm{x} \mathrm{g}$ for $12 \mathrm{~min}$ to achieve a single-cell suspension. HCC cells were isolated by repeated trypsinization and adhesion. The present study was approved by the institutional review board of Zhongshan Hospital, Fudan University (Shanghai, China). Written informed consent was obtained from all patients in accordance with the Declaration of Helsinki.

Cell culture. The human HCC cell lines, Huh7, 97H and L-02, were purchased from the Cell Bank of the Shanghai Institutes for Biological Science (Shanghai, China). Huh7, 97H, L-02 and freshly-isolated HCC cells were cultured in Dulbecco's modified Eagle's medium (DMEM) supplemented with $10 \%$ fetal bovine serum (FBS; Biowest, Nuaillé, France) and penicillin $(100 \mathrm{U} / \mathrm{ml}) /$ streptomycin $(100 \mathrm{mg} / \mathrm{ml})$. Cell cultures were maintained at $37^{\circ} \mathrm{C}$ in a humidified atmosphere with $5 \% \mathrm{CO}_{2}$. HCC cells were seeded in 6-, 24- or 96-well plates and incubated overnight for attachment. Following 24-h starvation, cells were treated with different concentrations of sorafenib (5, 10 and $20 \mu \mathrm{M})$ and $\mathrm{As}_{2} \mathrm{O}_{3}(0.5,1$ and $2 \mu \mathrm{M})$ for 24,48 and $72 \mathrm{~h}$. A medium-only group served as a negative control.

Cell Counting Kit-8 (CCK8) assay. The culture medium was discarded and $100 \mu 1$ serum-free DMEM was added to each well with $10 \mu \mathrm{l}$ CCK8 assay reagent (Dojindo Molecular Technologies, Inc., Kumamoto, Japan). After a 4-h incubation at $37^{\circ} \mathrm{C}$, the absorbance was measured at $450 \mathrm{nM}$ using a microplate reader (Molecular Devices, LLC, Sunnyvale, CA, USA). A total of 6 replicates were performed for each sample to obtain a mean value. The drug combination index value was calculated according to Jin's formula: $\mathrm{Q}=\mathrm{E}(\mathrm{A}+\mathrm{B}) /\left(\mathrm{EA}+\mathrm{EB}-\mathrm{EA}^{*} \mathrm{~EB}\right)(27) . \mathrm{E}(\mathrm{A}+\mathrm{B})$ being the inhibitory effect of the co-treatment of 2 drugs, while EA and EB are the inhibitory effects of the single drugs.

Apoptosis assay. Apoptosis was measured using an Annexin-V-FITC Apoptosis Detection kit (BD Bioscience, Franklin Lakes, NJ, USA), according to the manufacturer's protocol. Briefly, following single- or combined-agent drug treatments, $1 \times 10^{5}$ cells were washed twice with cold PBS and resuspended in $500 \mu \mathrm{l}$ binding buffer for Annexin-V and propidium iodide (PI) staining. After staining, 20,000 cells were analyzed using a FACS Arial II system (BD Biosciences). Annexin- $\mathrm{V}^{+} \mathrm{PI}^{-}$cells were analyzed as apoptotic and Annexin- $\mathrm{V}^{+} \mathrm{PI}^{+}$cells were regarded as necrotic cells.

RNA isolation and reverse transcription-quantitative polymerase chain reaction ( $R T-q P C R)$. Total RNA of HCC cells following single or combined treatment was isolated using TRIzol (Thermo Fisher Scientific, Inc., Waltham, MA, USA), according to the manufacturer's protocol. $1 \mathrm{mg}$ total RNA from each sample was reverse-transcribed to cDNA using a PrimeScript ${ }^{\circledR}$ RT reagent kit (Takara Bio, Inc., Otsu, Japan), according to the manufacturer's protocol. RT-qPCR was performed using SYBR ${ }^{\circledR}$ Premix Ex Taq ${ }^{\mathrm{TM}}$ (Takara Bio, Inc.), according to the manufacturer's protocol, and cDNA amplification was detected using a 7500 RT-PCR system (Applied Biosystems; Thermo Fisher Scientific, Inc.) for 40 cycles at $95^{\circ} \mathrm{C} 5 \mathrm{sec}$ and $60^{\circ} \mathrm{C} 30 \mathrm{sec}$. Relative gene expression was quantified using the $2^{-\Delta \Delta \mathrm{Cq}}$ method (28). The sequences of each primer used are listed in Table I (Invitrogen; Thermo Fisher Scientific, Inc.). 
Table I. Primer sequences of TRAIL and GAPDH for Real-time PCR.

\begin{tabular}{lll}
\hline Gene & \multicolumn{1}{c}{ Chains } & \multicolumn{1}{c}{ Primer sequence } \\
\hline GAPDH & Sense & AGAAGGCTGGGGCTCATTT \\
& Antisense & AGGGGCCATCCACAGTCTTC \\
TRAIL & Sense & GAAGCAACACATTGTCTTCTCAA \\
& Antisense & TTGCTCAGGAATGAATGCCC \\
\hline
\end{tabular}

TRAIL, TNF-related apoptosis-inducing ligand.

Table II. siRNA sequences of TRAIL and Negative control.

\begin{tabular}{lcc}
\hline siRNA & Chains & \multicolumn{1}{c}{ Primer sequence } \\
\hline TRAIL & Sense & UCCGUCAGCUCGUUAGAAATT \\
Negative & Sense & UUCUCCGAACGUGUCACGUdTd \\
control & & \\
\hline
\end{tabular}

siRNA, small interfering RNA; TRAIL, TNF-related apoptosis-inducing ligand.

Western blot analysis. Western blotting was performed as previously described (7). Briefly, HCC cells were harvested following single or combined drug treatment by scraping. The cells were incubated with lysis buffer $(1 \mathrm{mmol} / \mathrm{l}$ EGTA, $150 \mathrm{mmol} / 1 \mathrm{NaCl}, 1 \%$ Triton X-100, $2.5 \mathrm{mmol} / 1$ sodium pyrophosphate, $1 \mathrm{mmol} / \mathrm{l} \mathrm{PMSF}, 1 \mathrm{mmol} / 1 \mathrm{Na}_{3} \mathrm{VO}_{4}, 1 \mathrm{mg} / \mathrm{ml}$ leupeptin, $1 \mathrm{mg} / \mathrm{ml}$ aprotinin, $5 \mathrm{mmol} / \mathrm{l} \mathrm{NaF}$ in $20 \mathrm{mmol} / \mathrm{l}$ Tris- $\mathrm{HCl}$ buffer, $\mathrm{pH}$ 7.5). Cell lysates were centrifuged at $13,000 \times \mathrm{g}, 4^{\circ} \mathrm{C}$ for $30 \mathrm{~min}$. Protein concentration was determined using the BCA protein analysis (Thermo Fisher Scientific, Inc.) and $40 \mu \mathrm{g}$ of protein from each sample of protein were separated by $10 \%$ SDS-PAGE gels. The separated proteins were transferred onto PVDF membranes. After blocking with 5\% nonfat dry milk in double-distilled water at room temperature for $1 \mathrm{~h}$, membranes were washed 3 times with TBS containing $0.1 \%$ Tween (TBS-T) at room temperature for 5 min each time and incubated overnight at $4^{\circ} \mathrm{C}$ with anti-TRAIL (cat. no. 3219S; Cell Signaling Technology, Danvers, MA, USA) and anti-GAPDH (cat. no. 5174S; Cell Signaling Technology) at a 1:1,000 dilutions overnight. The membranes were washed 3 times with TBS-T at room temperature for $5 \mathrm{~min}$ each time, followed by $1 \mathrm{~h}$ incubation at room temperature in a 1:1,000 dilution of horseradish peroxidase conjugated goat anti-rabbit secondary antibody (cat. no. 111-035-003; Jackson Laboratory for Genomic Medicine, Farmington, CT, USA). Following incubation, membranes were washed 3 times with TBS-T and were visualized by enhanced chemiluminescence (Pierce ECL Western Blotting Substrate; Thermo Fisher Scientific, Inc.).

RNA silencing. TRAIL was downregulated in HCC cells using siRNA duplexes (GenePharma, Co., Ltd., Shanghai, China). Briefly, untreated Huh7 cells were seeded in a 6-well plate at
$5 \times 10^{5}$ cells per well, and incubated overnight for attachment. After growing to 80-90\% confluency, the cells were transfected with $20 \mathrm{nM}$ TRAIL siRNA or negative control (the sequences of all siRNA are listed in Table II) using Lipofectamine 2000 (Thermo Fisher Scientific, Inc.), according to the manufacturer's protocol, in Opti-MEM medium (Gibco; Thermo Fisher Scientific, Inc.) without FBS. A total of $6 \mathrm{~h}$ later, the media was replaced by DMEM containing 10\% FBS. A total of $24 \mathrm{~h}$ later, mRNA was used to detect the efficiency of transfection by RT-qPCR. After $48 \mathrm{~h}, \mathrm{HCC}$ cells were treated with $1 \mu \mathrm{M}$ $\mathrm{As}_{2} \mathrm{O}_{3}$ and $5 \mu \mathrm{M}$ sorafenib for further research.

Statistical analysis. All analyses were performed using SPSS software (version 13.0; SPSS Inc., Chicago, IL, USA). Data are expressed as the mean \pm standard error of the mean. Normality was assessed by Shapiro-Wilk test. One-way analysis of variance or Kruskal Wallis testing was used for normal or non-normal data, respectively. The least significant difference test was used for post-hoc multiple comparisons. $\mathrm{P}<0.05$ was considered to indicate a statistically significant difference.

\section{Results}

Effects of $\mathrm{As}_{2} \mathrm{O}_{3}$ and sorafenib alone and combined, on the proliferation of $\mathrm{Huh7}$ and $97 \mathrm{H}$ cells. To investigate the effect of $\mathrm{As}_{2} \mathrm{O}_{3}$ with and without sorafenib on liver cancer cell lines, Huh7 and 97H, cells were stimulated with drugs at different concentrations for $72 \mathrm{~h}$. Huh7 proliferation was significantly inhibited at high doses of $\mathrm{As}_{2} \mathrm{O}_{3}(2 \mu \mathrm{M}, 1.174 \pm 0.113$ vs. 2.882 \pm 0.007 , in $\mathrm{As}_{2} \mathrm{O}_{3}$-treated and control cells, respectively; $\mathrm{P}<0.01$; Fig. 1). Proliferation was suppressed at all concentrations of sorafenib alone, even at the lowest dose of $5 \mu \mathrm{M}$ $(1.564 \pm 0.070$ vs. $2.882 \pm 0.007$ in sorafenib-treated and control cells, respectively; $\mathrm{P}<0.01$, Fig. 1). Huh7-cell proliferation was inhibited in an $\mathrm{As}_{2} \mathrm{O}_{3}$-concnetration-dependent manner when treated with sorafenib in the presence of varying concentrations of $\mathrm{As}_{2} \mathrm{O}_{3}$ (Fig. 1). To determine whether the combined treatment had a synergistic impact on cell proliferation, the combination index values of each dose were calculated according to Jin's formula. At a concentration of $5 \mu \mathrm{M}$ sorafenib and $1 \mu \mathrm{M}$ $\mathrm{As}_{2} \mathrm{O}_{3}$, a synergistic effect was evident $(\mathrm{Q}=1.7>1.4)$. The effect on proliferation at high doses $(20 \mu \mathrm{M})$ of sorafenib and $\mathrm{As}_{2} \mathrm{O}_{3}$ resulted in cell death (Fig. 1). However, a synergistic effect was not detected in $97 \mathrm{H}$ cells. Inhibition of proliferation of 97H cells was evident only at high concentrations of sorafenib $(0.795 \pm 0.052$ vs. $1.495 \pm 0.015$, in $10 \mu \mathrm{M}$ sorafenib-treated and control cells, respectively; $\mathrm{P}<0.01 ; 0.359 \pm 0.034$ vs. $1.495 \pm 0.01520$ in $20 \mu \mathrm{M}$ sorafenib-treated and control cells, respectively; $\mathrm{P}<0.01$; Fig. 1).

Combined treatment of $\mathrm{As}_{2} \mathrm{O}_{3}$ and sorafenib increases cell death in Huh7 cells via TRAIL. When treated with $1 \mu \mathrm{M} \mathrm{As}_{2} \mathrm{O}_{3}$, or $5 \mu \mathrm{M}$ sorafenib, or a combination of the two drugs, for 24,48 and $72 \mathrm{~h}$, the apoptotic rate was significantly increased in Huh7 cells. Combination treatment demonstrated a synergistic effect on apoptosis and necrosis $(\mathrm{P}<0.01$; Fig. 2). After $72 \mathrm{~h}$ with combination treatment, almost all Huh7 cells were Annexin- $\mathrm{V}^{+}$(data not shown). Sorafenib resulted in significantly increased cell death after $48 \mathrm{~h}$ in normal liver (L-02) cells, but not after $24 \mathrm{~h}$ (Fig. 3). A number of genes associated with apoptosis were examined by 

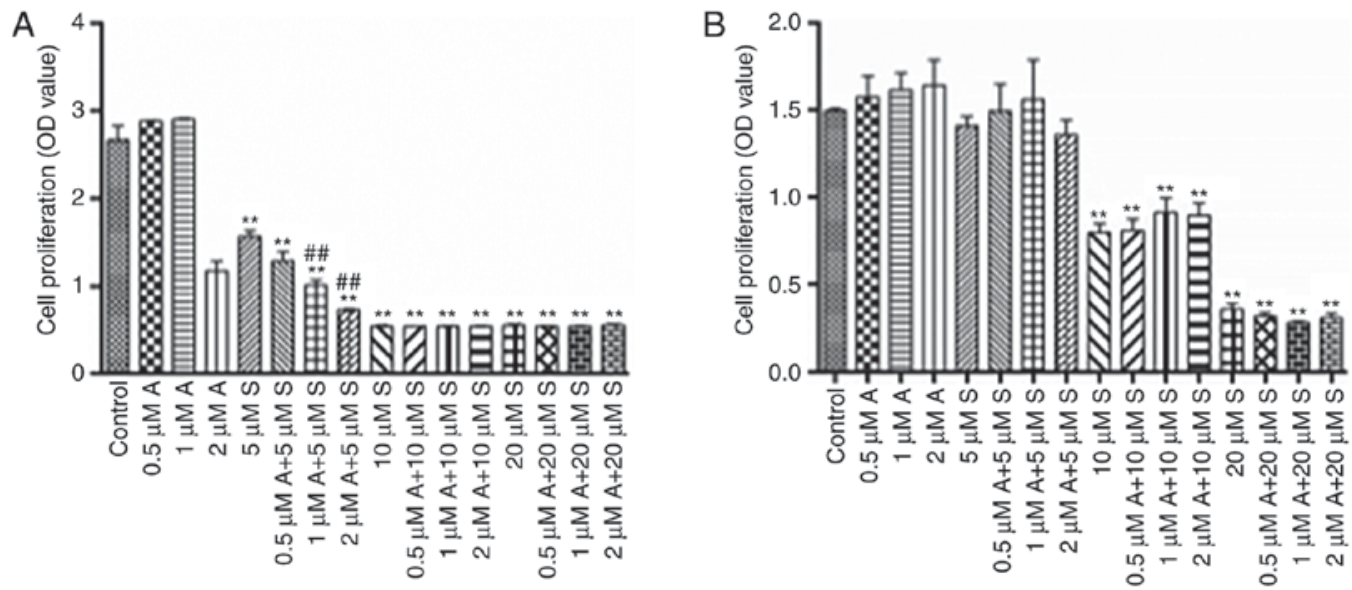

Figure 1. Effect of $\mathrm{As}_{2} \mathrm{O}_{3}$ and sorafenib, alone and combined, on cell proliferation. (A) The cell proliferation index of Huh7 cells, measured by CCK8 assay. (B) The cell proliferation index of $97 \mathrm{H}$ cells, measured by CCK8 assay. Data are presented as the mean \pm standard deviation and each experiment was repeated 6 times. ${ }^{* *} \mathrm{P}<0.01$, compared with control, ${ }^{\# \prime} \mathrm{P}<0.01$ compared with $5 \mu \mathrm{M}$ sorafenib alone. $\mathrm{A}, \mathrm{As}_{2} \mathrm{O}_{3} ; \mathrm{As}_{2} \mathrm{O}_{3}$, arsenic trioxide; $\mathrm{S}$, sorafenib; OD, optical density.
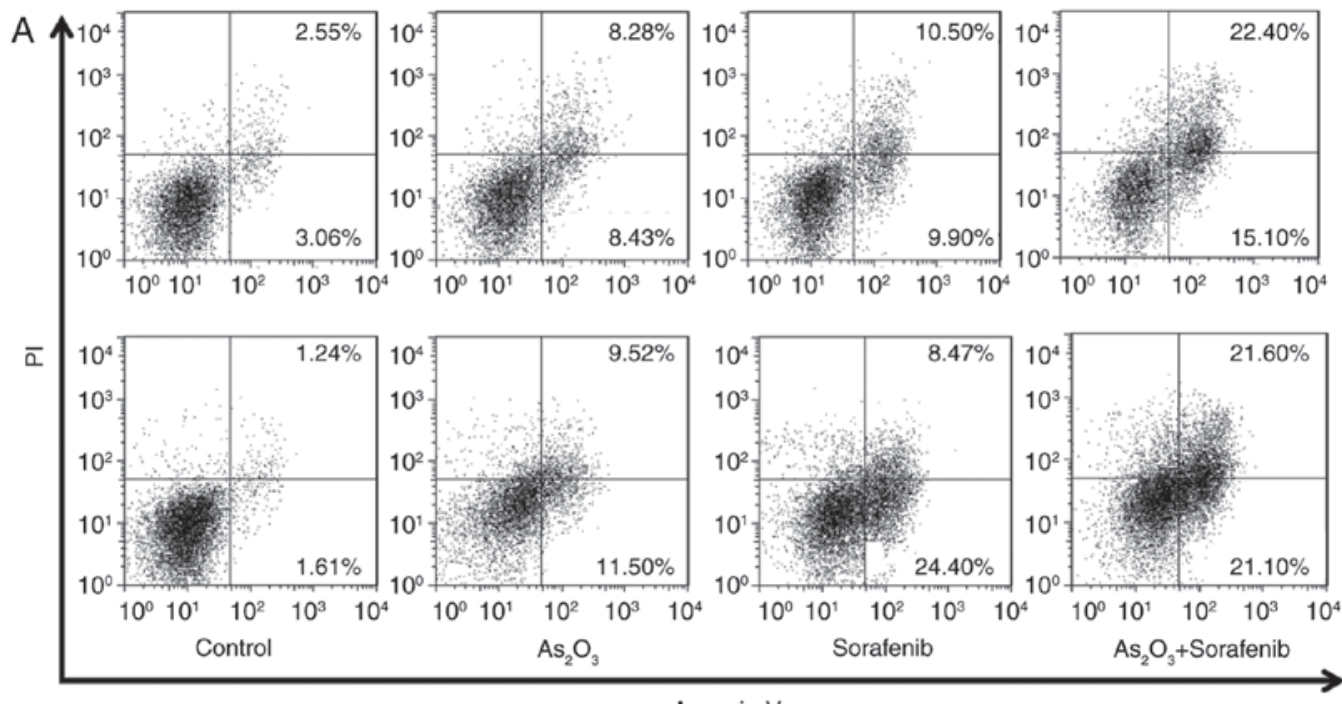

Annexin-V

B

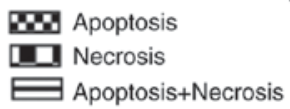

$24 \mathrm{~h}$

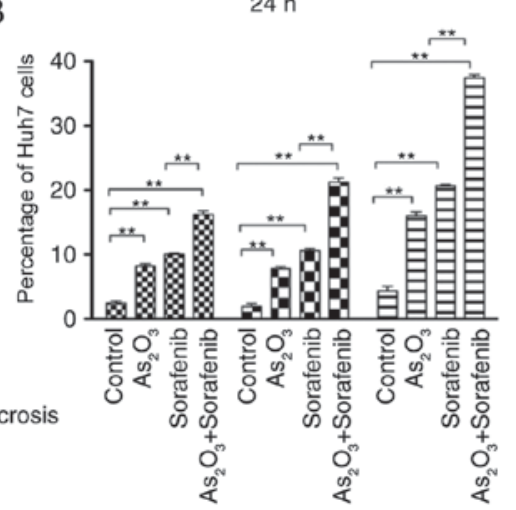

C

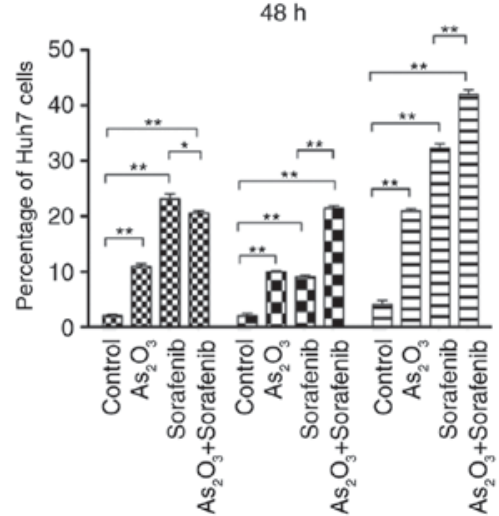

Figure 2. Combined $\mathrm{As}_{2} \mathrm{O}_{3}$ and sorafenib treatment induced apoptosis of Huh7 cells. (A) Huh7 cells were treated with $1 \mu \mathrm{M}$ As $2 \mathrm{O}_{3}$ and $5 \mu \mathrm{M}$ sorafenib alone or combined for 24 and $48 \mathrm{~h}$. (B) The percentages of apoptotic and necrotic cells at $24 \mathrm{~h}$ after treatment. (C) The percentages of apoptotic and necrotic cells at $48 \mathrm{~h}$ after treatment. Data are presented as mean \pm standard deviation and each measurement was repeated 3 times independently. ${ }^{* *} \mathrm{P}<0.01,{ }^{*} \mathrm{P}<0.05$. As $\mathrm{O}_{3}$, arsenic trioxide; PI, proprium iodide.

RT-qPCR (data not shown), which demonstrated that the gene expression of TRAIL selectively induced apoptosis in tumor cells (29). TRAIL expression was significantly upregulated in the combination treatment group compared with the control and single treatment groups (Fig. 4A). TRAIL protein expression levels demonstrated consistent results (Fig. 4B and C). 

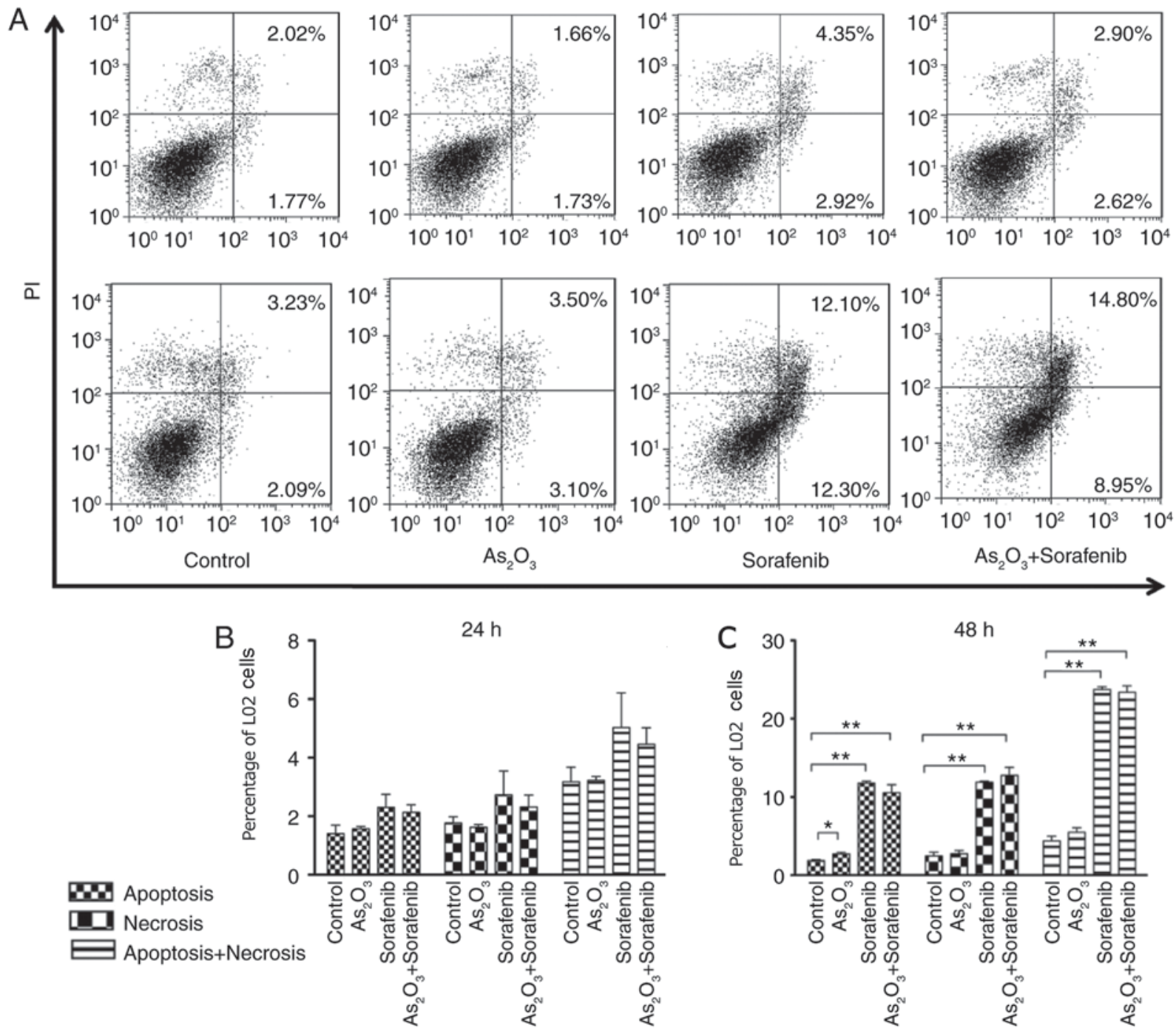

Figure 3. Synergistic effect of $\mathrm{As}_{2} \mathrm{O}_{3}$ and sorafenib on apoptosis of L-02 cells. (A) L- 02 cells were treated with $1 \mu \mathrm{M}$ As $\mathrm{O}_{3}$ and $5 \mu \mathrm{M}$ sorafenib alone or combined for 24 and $48 \mathrm{~h}$. Apoptotic cells were measured by Annexin-V/PI staining and flow cytometry. (B) The percentages of apoptotic and necrotic cells at $24 \mathrm{~h}$ after treatment. (C) The percentages of apoptotic and necrotic cells at $48 \mathrm{~h}$ after treatment. Data are presented as mean \pm standard deviation and each measurement was repeated 3 times independently. ${ }^{* *} \mathrm{P}<0.01,{ }^{*} \mathrm{P}<0.05$. $\mathrm{As}_{2} \mathrm{O}_{3}$, arsenic trioxide; PI, proprium iodide.

The synergistic effect of $\mathrm{As}_{2} \mathrm{O}_{3}$ and sorafenib on Huh7-cell death is dependent on TRAIL. In order to investigate whether the synergistic effect of sorafenib and $\mathrm{As}_{2} \mathrm{O}_{3}$ on Huh7-cell death occurred via a TRAIL-dependent pathway, TRAIL-targeted siRNA was used to downregulate TRAIL expression for $48 \mathrm{~h}$, after which the apoptosis of Huh7 cells was analyzed by flow cytometry. The synergistic effect of $\mathrm{As}_{2} \mathrm{O}_{3}$ and sorafenib on Huh7-cell apoptosis was reversed compared with negative control (Fig. 5).

$\mathrm{As}_{2} \mathrm{O}_{3}$ and Sorafenib combined treatment enhanced cell death in fresh isolated HCC cells. In order to investigate the clinical effect of $\mathrm{As}_{2} \mathrm{O}_{3}$ and sorafenib in combination, the anti-tumor activity of the combination treatment was analyzed in freshly isolated HCC cells. Annexin-V/PI staining was performed after $24 \mathrm{~h}$ treatment. The results revealed that cell death was significantly upregulated in the HCC-patient cells treated with $\mathrm{As}_{2} \mathrm{O}_{3}$ and sorafenib in combination $(\mathrm{P}<0.05$; Fig. 6). Sorafenib or $\mathrm{As}_{2} \mathrm{O}_{3}$ alone had no effect on tumor cell death in some of the HCC patients.

\section{Discussion}

HCC is a complex and heterogeneous type of tumor, associated with genomic aberrations (30). A number of signaling cascades, including mitogen-activated protein kinase (MAPK), VEGF and phosphoinositide-3-kinase (PI3K) have been demonstrated to be involved in HCC, and drugs have been designed to target these signaling pathways (31). Unfortunately, a number of these drugs, including brivanib, sunitinib and erlotinib, failed phase III clinical trials (32). Sorafenib, a multikinase inhibitor, remains the standard treatment for patients with advanced-stage hepatocellular carcinoma (33). The standard initial dose of sorafenib is $400 \mathrm{mg}$, taken orally, twice daily (34). The high dosage required can present financial and physical burdens for patients (35). Various adverse effects, including severe skin rash can occur following sorafenib administration (36). Therefore, novel therapeutic approaches to improve sorafenib efficacy at lower dosages are urgently required.

Previous studies have demonstrated that synergistic sorafenib therapy such as sorafenib combined with TACE 


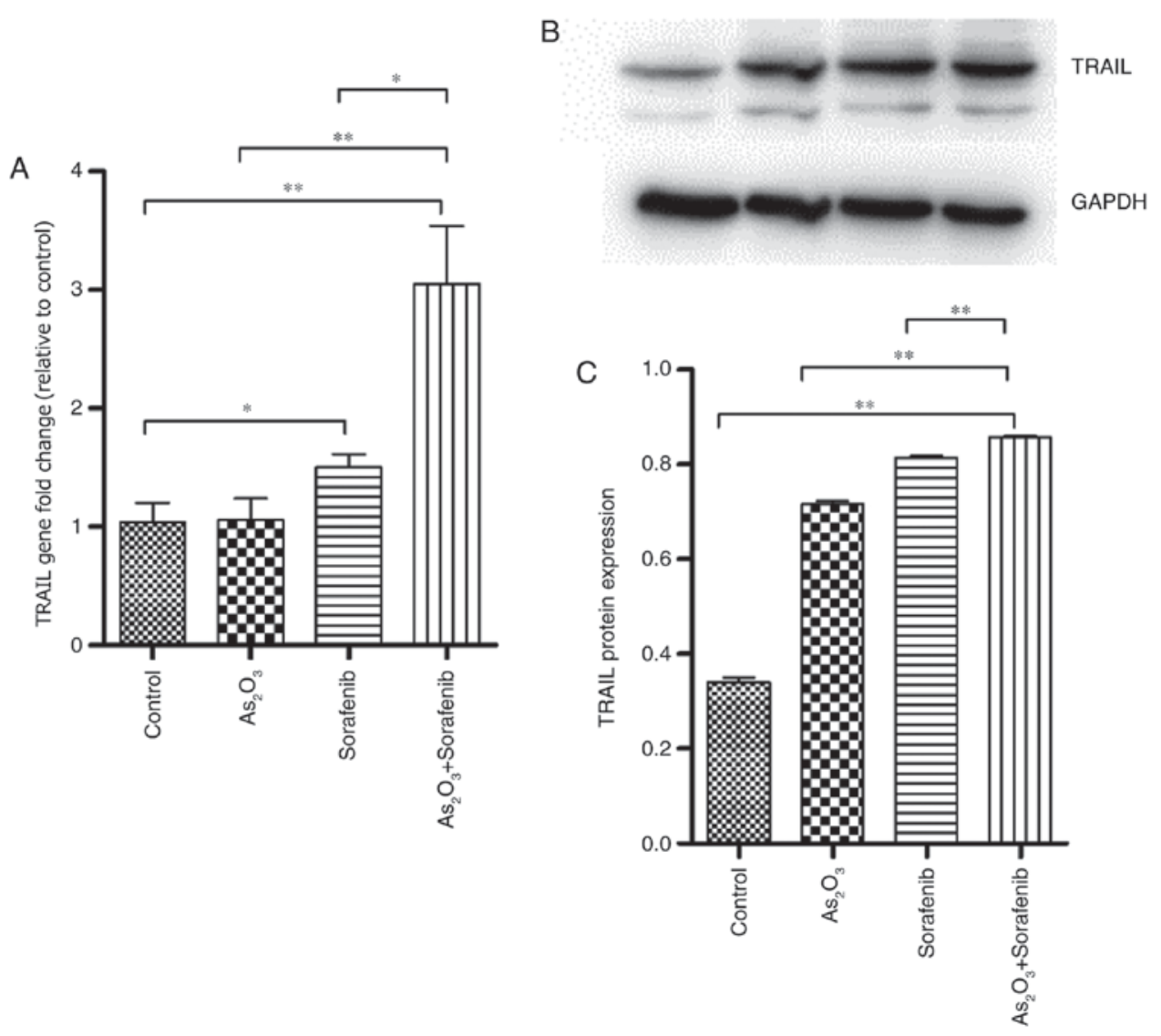

Figure 4. The expression level of TRAIL in Huuh7 cells treated with $\mathrm{As}_{2} \mathrm{O}_{3}$ and sorafenib, alone and combined. (A) Expression levels of TRAIL were analyzed by reverse transcription-quantitative polymerase chain reaction and normalized to the levels of GAPDH. (B) The protein expression level of TRAIL $24 \mathrm{~h}$ after was measured by western blotting, using GAPDH was used as a loading control. (C) The quantified relative protein expression level of TRAIL. Data are presented as mean \pm standard deviation and each measurement was repeated 3 times independently. ${ }^{* *} \mathrm{P}<0.01,{ }^{*} \mathrm{P}<0.05$. TRAIL, TNF-related apoptosis-inducing ligand; $\mathrm{As}_{2} \mathrm{O}_{3}$, arsenic trioxide.

or hepatic arterial infusion chemotherapy can enhance its antitumor activity (37). $\mathrm{As}_{2} \mathrm{O}_{3}$ is currently the most effective single agent treatment of APL, with a dose of $0.16 \mathrm{mg} / \mathrm{kg} /$ day allowing complete remission with lower-dose chemotherapy (38). Furthermore, $\mathrm{As}_{2} \mathrm{O}_{3}$ has been demonstrated to suppress tumor growth in liver, prostate and breast cancer through demethylation/apoptosis pathways (39). Research has demonstrated that $\mathrm{As}_{2} \mathrm{O}_{3}$ induced growth arrest of liver cancer, HepG2 and HepG3B, cells via activation of FOXO3a $(39,40)$. Furthermore, minimal side effects of $\mathrm{As}_{2} \mathrm{O}_{3}$ treatment have been observed (41). Thus, the combination of $\mathrm{As}_{2} \mathrm{O}_{3}$ and sorafenib has been hypothesized to have potential for effective treatment of $\mathrm{HCC}(21)$.

Although the present study demonstrated that $\mathrm{As}_{2} \mathrm{O}_{3}$ combined with sorafenib executes an anti-tumor effect by triggering cell death in Huh7 cells, this was not observed in $97 \mathrm{H}$ cells. One reason for this difference may be different status of cell differentiation. Another is that Huh7 cells are characterized as HBV-negative whereas $97 \mathrm{H}$ are $\mathrm{HBV}$-positive. HBV virus status has been associated with the effectiveness of sorafenib treatment, HBV-negative patients receiving sorafenib treatment had an improved OS time (42). HBV virus status may also influence the effect of $\mathrm{As}_{2} \mathrm{O}_{3}$ combined with sorafenib on HCC cells. Despite the cell type specificity, an advantage of the combination is the potential for a decreased dosage of sorafenib. An in vitro dosage of $5 \mu \mathrm{M}$ sorafenib with $\mathrm{As}_{2} \mathrm{O}_{3}$ corresponds to $50 \%$ the therapeutic plasma level of sorafenib in patients with $\mathrm{HCC}$ receiving $400 \mathrm{mg}$ sorafenib twice daily $(43,44)$. Furthermore, no significant side effects were demonstrated in the normal liver cell line after $24 \mathrm{~h}$ combination treatment, while sorafenib alone was toxic at $48 \mathrm{~h}$. This may be associated with the previously reported dose-limiting toxicities of sorafenib (45). These findings indicate that even at a low dosage of $5 \mu \mathrm{M}$, sorafenib impacts the viability of normal liver cells, further supporting the investigation of combined regimens, to achieve improved anti-tumor efficacy and minimized toxicity.

Programmed cell death (PCD) is an important cellular mechanism whose dysregulation has been reported to be involved in tumor formation (46). Induction of PCD is the best-characterized cause of cell death in most cell types (47). Seeing as $\mathrm{As}_{2} \mathrm{O}_{3}$ and sorafenib induce apoptosis in human cancer cell lines $(48,49)$, the synergic effect of sorafenib with $\mathrm{As}_{2} \mathrm{O}_{3}$ on human liver cancer cell apoptosis pathways was investigated. It was revealed that TRAIL, closely associated with PCD (50), was upregulated in the $\mathrm{As}_{2} \mathrm{O}_{3}$ and sorafenib combined-treatment group compared with untreated cells. Downregulation of TRAIL expression in the combined group significantly reduced the rate of PCD in HCC cells. These results indicate a close association between TRAIL and PCD-induction in HCC. TRAIL not only serves a role in induction of cell death, but also as a key effector in the immune system (51). It has been demonstrated that $\mathrm{TRAIL}^{-/}$mice were more susceptible to autoimmune diseases 

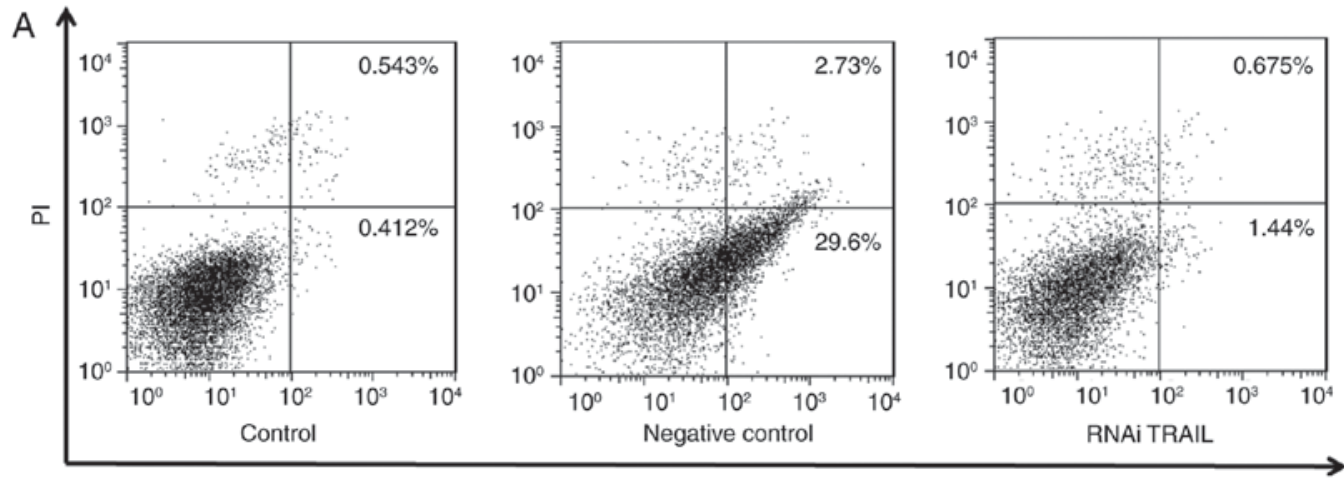

Annexin- $V$

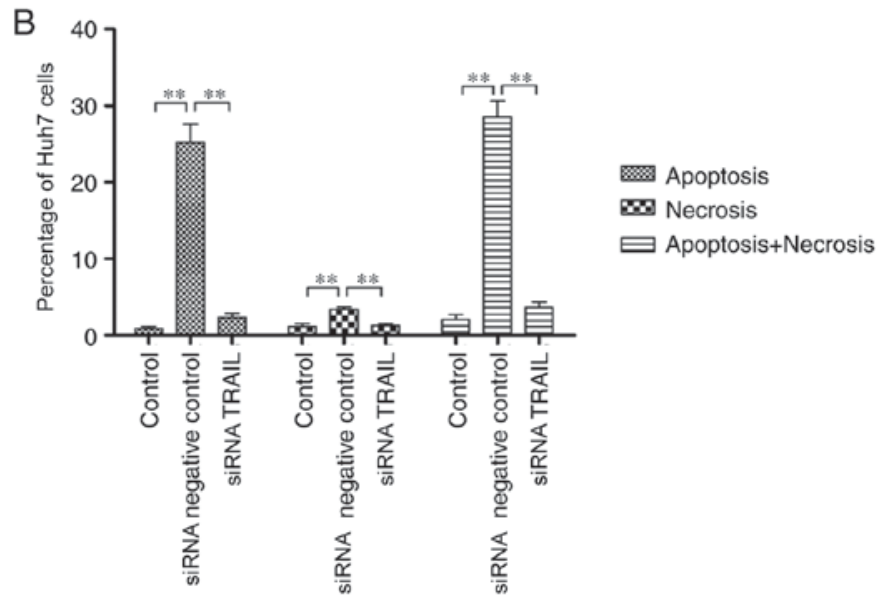

Figure 5. TRAIL siRNA significantly reduced the effect of combined $\mathrm{As}_{2} \mathrm{O}_{3}$ and sorafenib. (A) Huh7 cells were transfected with 20 nM siRNA for 48 h. After transfection, cells were treated with $1 \mu \mathrm{M} \mathrm{As}_{2} \mathrm{O}_{3}$ and $5 \mu \mathrm{M}$ sorafenib. Apoptotic cells were measured by Annexin-V/PI staning and flow cytometry. (B) The percentage of apoptosis and necrosis at $24 \mathrm{~h}$ after treatment. Data are presented as mean \pm standard deviation and each measurement was repeated 3 times independently. ${ }^{* *} \mathrm{P}<0.05$. TRAIL, TNF-related apoptosis-inducing ligand; siRNA, small interfering $\mathrm{RNA}$, $\mathrm{As}_{2} \mathrm{O}_{3}$, arsenic trioxide; $\mathrm{PI}$, proprium iodide.

such as arthritis and diabetes (52). Further study is required to investigate whether the $\mathrm{As}_{2} \mathrm{O}_{3}$ and sorafenib combination causes HCC-cell death by impacting the tumor immune microenvironment as well as inducing tumor-cell PCD.

To determine the value of the combination of $\mathrm{As}_{2} \mathrm{O}_{3}$ and sorafenib in clinical practice, freshly isolated $\mathrm{HCC}$ cells were collected from HCC patients who underwent surgery. The results confirmed that the combination treatment induces HCC-cell death. This result supports further clinical investigations of this combined treatment, particularly as the primary HCC cells were only sensitive to the combined treatment, and not to sorafenib or $\mathrm{As}_{2} \mathrm{O}_{3}$ alone. Recently, it has been reported that targeted TRAIL gene therapy may provide a potential strategy for HCC therapy in a preclinical setting (53). The results of the present study suggest that targeted TRAIL therapy, based on the success of sorafenib/ $\mathrm{As}_{2} \mathrm{O}_{3}$ treatment, may benefit patients with HCC.

The present study demonstrates that $\mathrm{As}_{2} \mathrm{O}_{3}$ and sorafenib combination treatment causes HCC-cell death via the TRAIL signaling pathway. Furthermore, the combination had potent anti-tumor activity in freshly isolated HCC cells from patients with HCC patients, while these cells were resistant to the treatment of sorafenib or $\mathrm{As}_{2} \mathrm{O}_{3}$ alone. The authors acknowledge that these findings need to be validated in vivo. However, the significance of the present study lies with the potential of a novel therapeutic target. Therefore, clinical research of
$\mathrm{As}_{2} \mathrm{O}_{3}$ and sorafenib combination treatment of HCC should be prioritized. However, the anti-tumor activity of this combination was demonstrated to be cell type specific, which is likely associated with the HBV virus infection. The underlying mechanisms of this effect also require further investigation.

\section{Acknowledgements}

Not applicable.

\section{Funding}

The present study was supported by grants from National Natural Science Foundation of China (grant nos. 81470282 and 81170473) and Zhongshan Hospital (grant no., 2015ZSYXGG09).

\section{Availability of data and materials}

All data generated or analyzed during this study are included in this published article.

\section{Authors' contributions}

YW and YC conceived the study. LW, YW and YC performed the literature review, and drafted and revised the manuscript. 

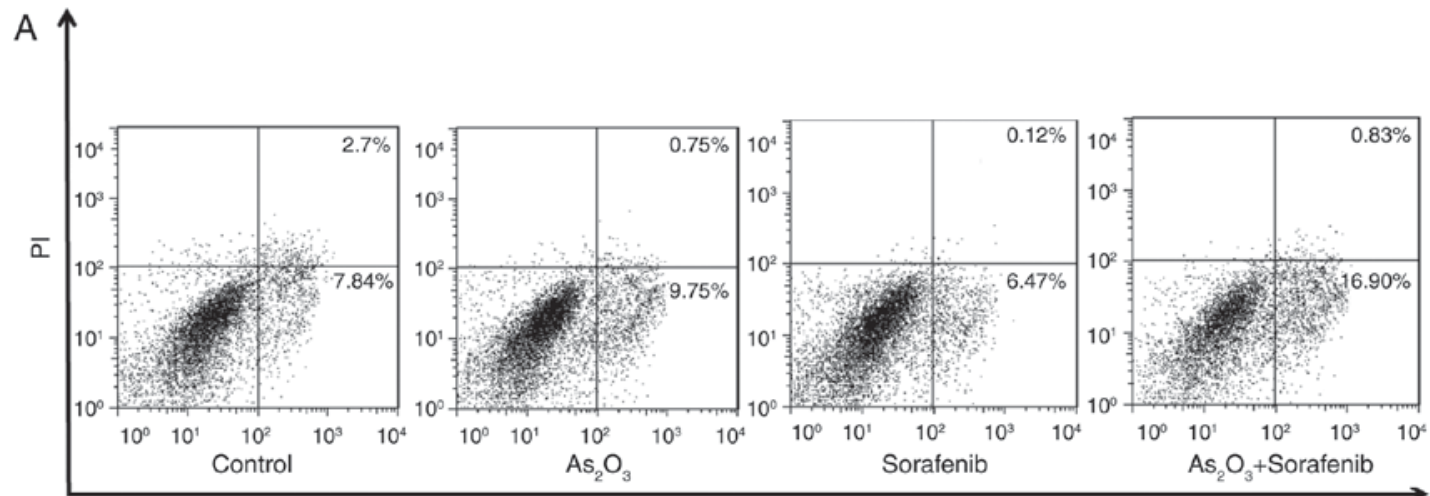

Annexin-V
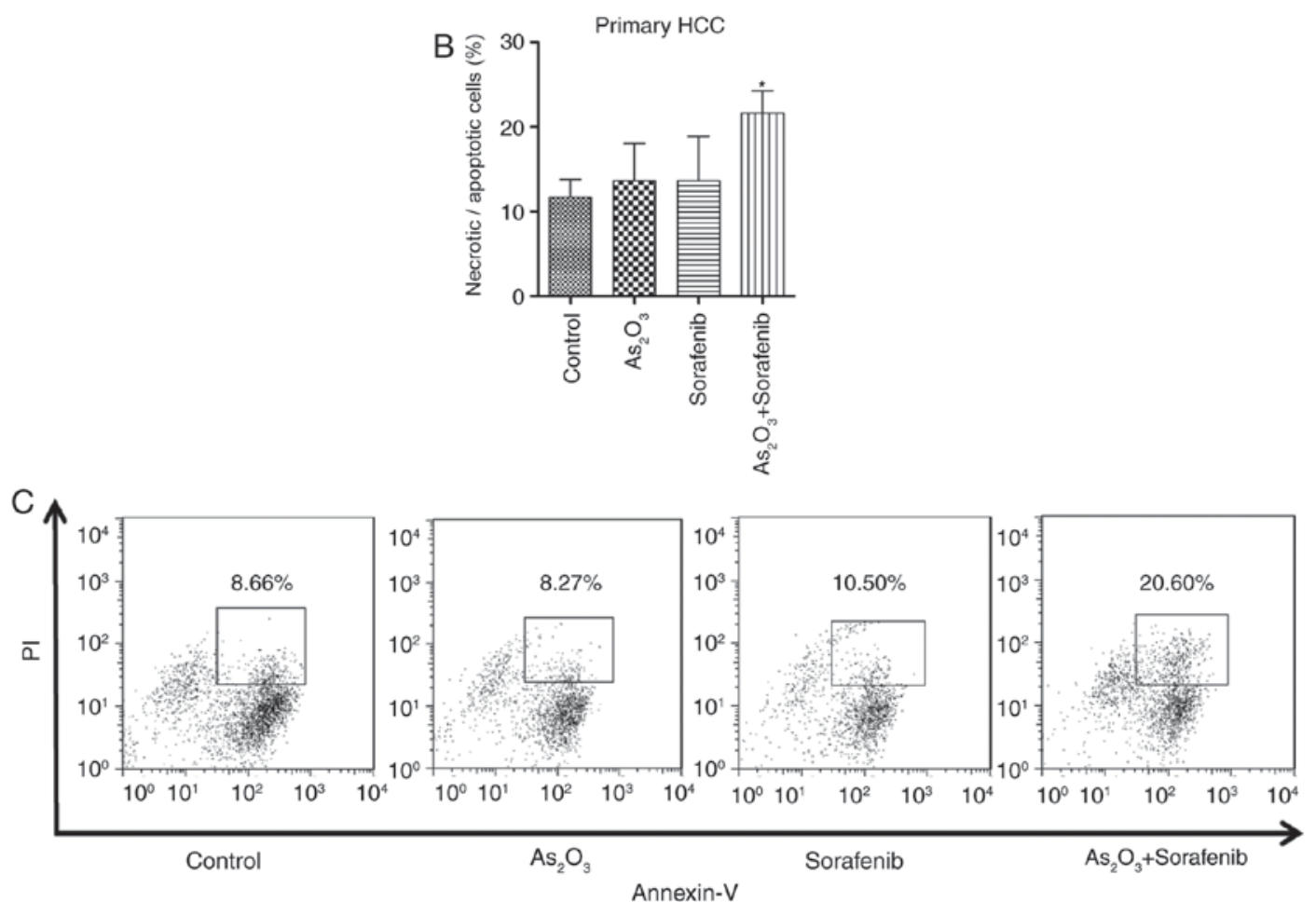

Figure 6. Combined effect of $\mathrm{As}_{2} \mathrm{O}_{3}$ and sorafenib on cell apoptosis in freshly isolated HCC cells. (A) Rate of apoptosis of HCC cells following treatment with $\mathrm{As}_{2} \mathrm{O}_{3}$ and sorafenib, alone or combined, for $24 \mathrm{~h}$. (B) The percentage of cells undergoing programmed cell death. (C) An example of the effect of $\mathrm{As}_{2} \mathrm{O}_{3}$ and/or sorafenib treatment on HCC cells isolated from fresh patient tissue. Data are presented as mean \pm standard deviation and each measurement was repeated 10 times independently. ${ }^{*} \mathrm{P}<0.05 . \mathrm{As}_{2} \mathrm{O}_{3}$, arsenic trioxide; $\mathrm{HCC}$, hepatocellular carcinoma; PI, proprium iodide.

YW and YC critically revised the manuscript. LW, ZM, XW, $\mathrm{MH}, \mathrm{DS}$ and ZR performed the experiments and analyzed data. All authors read and approved the final manuscript.

\section{Ethics approval and consent to participate}

The present study was performed in accordance with the ethical standards formulated in the Declaration of Helsinki, and was approved by Medical Ethics Committee of Zhongshan Hospital (Fudan University, Shanghai, China). Written informed consent was obtained from each patient prior to inclusion in the present study.

\section{Consent for publication}

All participants provided written informed consent for the publication of any associated data and accompanying images.

\section{Competing interests}

The authors declare that they have no competing interests.

\section{References}

1. Yang Y, Zhao LH, Huang B, Wang RY, Yuan SX, Tao QF, Xu Y, Sun HY, Lin C and Zhou WP: Pioglitazone, a PPAR $\gamma$ agonist, inhibits growth and invasion of human hepatocellular carcinoma via blockade of the rage signaling. Mol Carcinog 54: 1584-1595, 2015.

2. Mgaieth S, Kemp W, Gow P, Fink M, Lubel J, Nicoll A, Gazzola A, Hong T, Ryan M and Knight V: Impact of viral hepatitis aetiology on survival outcomes in hepatocellular carcinoma: A large multicentre cohort study. J Viral Hepat 24: 982-989, 2017.

3. Tornai I: Role of environmental factors in the etiology of hepatocellular carcinoma. Orv Hetil 151: 1132-1136, 2010 (In Hungarian).

4. Lischalk JW, Repka MC and Unger K: Radiation therapy for hepatobiliary malignancies. J Gastrointest Oncol 8: 279-292, 2017. 
5. Rich NE, Parikh ND and Singal AG: Hepatocellular carcinoma and liver transplantation: Changing patterns and practices. Curr Treat Options Gastroenterol 15: 296-304, 2017.

6. Yu WB, Rao A, Vu V, Xu L, Rao JY and Wu JX: Management of centrally located hepatocellular carcinoma: Update 2016. World J Hepatol 9: 627-634, 2017.

7. Chen $\mathrm{CH}$, Chen MC, Wang JC, Tsai AC, Chen CS, Liou JP, Pan SL and Teng CM: Synergistic interaction between the HDAC inhibitor, MPT0E028, and sorafenib in liver cancer cells in vitro and in vivo. Clin Cancer Res 20: 1274-1287, 2014.

8. Zhu YJ, Zheng B, Wang HY and Chen L: New knowledge of the mechanisms of sorafenib resistance in liver cancer. Acta Pharmacol Sin 38: 614-622, 2017.

9. Cheng AL, Kang YK, Chen Z, Tsao CJ, Qin S, Kim JS, Luo R, Feng J, Ye S, Yang TS, et al: Efficacy and safety of sorafenib in patients in the Asia-Pacific region with advanced hepatocellular carcinoma: A phase III randomised, double-blind, placebo-controlled trial. Lancet Oncol 10: 25-34, 2009.

10. Liu LL, Zhang MF, Pan YH, Yun JP and Zhang CZ: NORE1A sensitises cancer cells to sorafenib-induced apoptosis and indicates hepatocellular carcinoma prognosis. Tumour Biol 35 1763-1774, 2014.

11. Karashima T, Komatsu T, Niimura M, Kawada C, Kamada M, Inoue K, Udaka K, Kuroda N and Shuin T: Novel combination therapy with imiquimod and sorafenib for renal cell carcinoma. Int J Urol 21: 702-706, 2014.

12. Luu T, Frankel P, Chung C, Chow W, Mortimer J, Hurria A and Somlo G: Phase I/II trial of vinorelbine and sorafenib in metastatic breast cancer. Clin Breast Cancer 14: 94-100, 2014

13. Ravandi F, Arana Yi C, Cortes JE, Levis M, Faderl S, Garcia-Manero G, Jabbour E, Konopleva M, O'Brien S, Estrov Z, et al: Final report of phase II study of sorafenib, cytarabine and idarubicin for initial therapy in younger patients with acute myeloid leukemia. Leukemia 28: 1543-1545, 2014.

14. Wörns MA and Galle PR: HCC therapies-lessons learned. Nat Rev Gastroenterol Hepatol 11: 447-452, 2014.

15. Emadi A and Gore SD: Arsenic trioxide-An old drug rediscovered. Blood Rev 24: 191-199, 2010.

16. Miller WH Jr, Schipper HM, Lee JS, Singer J and Waxman S: Mechanisms of action of arsenic trioxide. Cancer Res 62: 3893-3903, 2002.

17. Zheng CY, Lam SK, Li YY, Fong BM, Mak JC and Ho JC: Combination of arsenic trioxide and chemotherapy in small cell lung cancer. Lung Cancer 82: 222-230, 2013.

18. Thomas-Schoemann A, Batteux F, Mongaret C, Nicco C, Chéreau C, Annereau M, Dauphin A, Goldwasser F, Weill B, Lemare $\mathrm{F}$ and Alexandre J: Arsenic trioxide exerts antitumor activity through regulatory $\mathrm{T}$ cell depletion mediated by oxidative stress in a murine model of colon cancer. J Immunol 189 5171-5177, 2012

19. Yang X, Sun D, Tian Y, Ling S and Wang L: Metformin sensitizes hepatocellular carcinoma to arsenic trioxide-induced apoptosis by downregulating Bcl2 expression. Tumour Biol 36: 2957-2964, 2015.

20. Lin CC, Hsu C, Hsu CH, Hsu WL, Cheng AL and Yang CH: Arsenic trioxide in patients with hepatocellular carcinoma: A phase II trial. Invest New Drugs 25: 77-84, 2007.

21. Zhai B, Jiang X, He C, Zhao D, Ma L, Xu L, Jiang H and Sun X: Arsenic trioxide potentiates the anti-cancer activities of sorafenib against hepatocellular carcinoma by inhibiting Akt activation. Tumour Biol 36: 2323-2334, 2015.

22. Moloudi K, Neshasteriz A, Hosseini A, Eyvazzadeh N, Shomali M, Eynali S, Mirzaei E and Azarnezhad A: Synergistic effects of arsenic trioxide and radiation: Triggering the intrinsic pathway of apoptosis. Iran Biomed J 21: 330-337, 2017.

23. Xu Y, Li J, Li QJ, Feng YL and Pan F: Betulinic acid promotes TRAIL function on liver cancer progression inhibition through p53/Caspase-3 signaling activation. Biomed Pharmacother 88: 349-358, 2017

24. Kong X, Luo J, Xu T, Zhou Y, Pan Z, Xie Y, Zhao L, Lu Y Han X, Li Z and Liu L: Plumbagin enhances TRAIL-induced apoptosis of human leukemic Kasumi-1 cells through upregulation of TRAIL death receptor expression, activation of caspase- 8 and inhibition of cFLIP. Oncol Rep 37: 3423-3432, 2017.

25. Clarke N, Jimenez-Lara AM, Voltz E and Gronemeyer H: Tumor suppressor IRF-1 mediates retinoid and interferon anticancer signaling to death ligand TRAIL. EMBO J 23: 3051-3060, 2004

26. Cretney E, Takeda K, Yagita H, Glaccum M, Peschon JJ and Smyth MJ: Increased susceptibility to tumor initiation and metastasis in TNF-related apoptosis-inducing ligand-deficient mice. J Immunol 168: 1356-1361, 2002.
27. Zhang H, Liu K, Xue Z, Yin H, Dong H, Jin W, Shi X, Wang H and Wang H: High-voltage pulsed electric field plus photodynamic therapy kills breast cancer cells by triggering apoptosis. Am J Transl Res 10: 334-351, 2018.

28. Livak KJ and Scmittgen TD: Analysis of relative gene expression data using real-time quantitative PCR and the 2(-Delta Delta C(T)) method. Methods 25: 402-408, 2001.

29. Hellwig CT and Rehm M: TRAIL signaling and synergy mechanisms used in TRAIL-based combination therapies. Mol Cancer Ther 11: 3-13, 2012.

30. Cho HJ, Kim SS, Wang HJ, Kim BW, Cho H, Jung J, Cho SS, Kim JK, Lee JH, Kim YB, et al: Detection of novel genomic markers for predicting prognosis in hepatocellular carcinoma patients by integrative analysis of copy number aberrations and gene expression profiles: Results from a long-term follow-up. DNA Cell Biol 35: 71-80, 2016.

31. Ho DW, Lo RC, Chan LK and Ng IO: Molecular pathogenesis of hepatocellular carcinoma. Liver Cancer 5: 290-302, 2016.

32. Llovet JM and Hernandez-Gea V: Hepatocellular carcinoma: Reasons for phase III failure and novel perspectives on trial design. Clin Cancer Res 20: 2072-2079, 2014.

33. Abeni E, Salvi A, Marchina E, Traversa M, Arici B and De Petro G: Sorafenib induces variations of the DNA methylome in HA22T/VGH human hepatocellular carcinoma-derived cells. Int J Oncol 51: 128-144, 2017.

34. Kobayashi S, Ohkawa S, Kondo M, Morimoto M, Numata K, Matsunaga K, Okuse C, Suzuki M, Hidaka H, Takada J, et al: Influence of body surface area on efficacy and safety of sorafenib in advanced hepatocellular carcinoma. Gan To Kagaku Ryoho 39: 1065-1070, 2012 (In Japanese).

35. Ziogas IA and Tsoulfas G: Evolving role of Sorafenib in the management of hepatocellular carcinoma. World J Clin Oncol 8: 203-213, 2017.

36. Tsuchiya N, Narita S, Inoue T, Hasunuma N, Numakura K, Horikawa Y, Satoh S, Notoya T, Fujishima N, Hatakeyama S, et al: Risk factors for sorafenib-induced high-grade skin rash in Japanese patients with advanced renal cell carcinoma. Anticancer Drugs 24: 310-314, 2013.

37. Kudo M: Signaling pathway/molecular targets and new targeted agents under development in hepatocellular carcinoma. World J Gastroenterol 18: 6005-6017, 2012.

38. Breccia M and Lo-Coco F: Arsenic trioxide for management of acute promyelocytic leukemia: Current evidence on its role in front-line therapy and recurrent disease. Expert Opin Pharmacother 13: 1031-1043, 2102

39. Wang X, Jiang F, Mu J, Ye X, Si L, Ning S, Li Z and Li Y: Arsenic trioxide attenuates the invasion potential of human liver cancer cells through the demethylation-activated microRNA-491. Toxicol Lett 227: 75-83, 2014

40. Fei M, Lu M, Wang Y, Zhao Y, He S, Gao S, Ke Q, Liu Y, Li P, Cui $\mathrm{X}$, et al: Arsenic trioxide-induced growth arrest of human hepatocellular carcinoma cells involving FOXO3a expression and localization. Med Oncol 26: 178-185, 2009.

41. Rangwala F, Williams KP, Smith GR, Thomas Z, Allensworth JL, Lyerly HK, Diehl AM, Morse MA and Devi GR: Differential effects of arsenic trioxide on chemosensitization in human hepatic tumor and stellate cell lines. BMC Cancer 12: 402, 2012.

42. Jackson R, Psarelli EE, Berhane S, Khan H and Johnson P. Impact of viral status on survival in patients receiving sorafenib for advanced hepatocellular cancer: A meta-analysis of randomized phase III trials. J Clin Oncol 35: 622-628, 2017.

43. Alsaied OA, Sangwan V, Banerjee S, Krosch TC, Chugh R, Saluja A, Vickers SM and Jensen EH: Sorafenib and triptolide as combination therapy for hepatocellular carcinoma. Surgery 156: 270-279, 2014.

44. Hu S, Niu H, Inaba H, Orwick S, Rose C, Panetta JC, Yang S, Pounds S, Fan Y, Calabrese C, et al: Activity of the multikinase inhibitor sorafenib in combination with cytarabine in acute myeloid leukemia. J Natl Cancer Inst 103: 893-905, 2011.

45. Abou-Alfa GK, Schwartz L, Ricci S, Amadori D, Santoro A, Figer A, De Greve J, Douillard JY, Lathia C, Schwartz B, et al: Phase II study of sorafenib in patients with advanced hepatocellular carcinoma. J Clin Oncol 24: 4293-4300, 2006.

46. Mishra AP, Salehi B, Sharifi-Rad M, Pezzani R, Kobarfard F, Sharifi-Rad J and Nigam M: Programmed cell death, from a cancer perspective: An overview. Mol Diagn Ther: Mar 20, 2018 (Epub ahead of print).

47. Voigt S, Philipp S, Davarnia P, Winoto-Morbach S, Röder C, Arenz C, Trauzold A, Kabelitz D, Schütze S, Kalthoff H and Adam D: TRAIL-induced programmed necrosis as a novel approach to eliminate tumor cells. BMC Cancer 14: 74, 2014. 
48. Oh SJ, Erb HH, Hobisch A, Santer FR and Culig Z: Sorafenib decreases proliferation and induces apoptosis of prostate cancer cells by inhibition of the androgen receptor and Akt signaling pathways. Endocr Relat Cancer 19: 305-319, 2012.

49. Zhang XH, Feng R, Lv M, Jiang Q, Zhu HH, Qing YZ, Bao JL, Huang XJ and Zheng XL: Arsenic trioxide induces apoptosis in B-cell chronic lymphocytic leukemic cells through down-regulation of survivin via the p53-dependent signaling pathway. Leuk Res 37: 1719-1725, 2013.

50. Liu JJ, Wang W, Dicker DT and El-Deiry WS: Bioluminescent imaging of TRAIL-induced apoptosis through detection of caspase activation following cleavage of DEVD-aminoluciferin. Cancer Biol Ther 4: 885-892, 2005.
51. Diao Z, Shi J, Zhu J, Yuan H, Ru Q, Liu S, Liu Y and Zheng D: TRAIL suppresses tumor growth in mice by inducing tumor-infiltrating CD4(+)CD25 (+) Treg apoptosis. Cancer Immunol Immunother 62: 653-663, 2013.

52. Lamhamedi-Cherradi SE, Zheng SJ, Maguschak KA, Peschon $\mathrm{J}$ and Chen $\mathrm{YH}$ : Defective thymocyte apoptosis and accelerated autoimmune diseases in TRAIL-/- mice. Nat Immunol 4: 255-260, 2003.

53. Galal El-Shemi A, Mohammed Ashshi A, Oh E, Jung BK, Basalamah M, Alsaegh A and Yun CO: Efficacy of combining ING4 and TRAIL genes in cancer-targeting gene virotherapy strategy: First evidence in preclinical hepatocellular carcinoma. Gene Ther 25: 54-65, 2018. 